\title{
The moment of truth for science
}

\author{
The consequences of the 'knowledge society' for society and science • by Peter Weingart
}

Science is probably the fastest growing enterprise in our society. Since the 17 th Century, every doubling of the population has seen a tripling in the number of scientists (Price, 1971). This means that, over the last 300 years, Western societies have invested a major part of their resources into the production, revision and verification of knowledge. It is a process that perpetuates itself if sufficiently nourished-the more resources go into science, the more scientists are educated, the more results they produce and the more questions arise. In this regard, the frontiers of science are indeed endless, to paraphrase Vannevar Bush's slogan. The exponential growth of science is seen as the main factor in the shift from an industrialised society to a knowledge society (Bell, 1973).

Any analysis of science and its impact on all other parts of society, such as politics, law, economics or the media, must take into account these astonishing dynamics, its causes and its consequences. And vice versa-science's expansion has repercussions not only for society but also for science. One mechanism to cope with this exponential growth has been differentiation. This strategic response is also observed in economic markets and organisations-if the competition increases, the incentive to create new 'niches' grows. The nature of these niches depends on the current alternatives and on the available resources (Whitley, 1984) - an explanation for why well-funded research areas, such as molecular biology, attract a high number of researchers and are highly competitive at the same time.

One form of differentiation is a greater abstraction towards 'a deeper understanding of the postulated structures of the object' (Stichweh, 1984). Science absorbs less knowledge from the outside but increasingly specialises in sorting, categorising and reconstructing its own knowledge in ever smaller fields. The German physicist Hermann von Helmholtz observed this more than 100 years ago: 'The obvious result is seen in the fact that every individual researcher is forced to select an ever smaller field for his research and can maintain only an incomplete knowledge of neighbouring fields' (von Helmholtz, 1896). The outstanding 'heroes' of science, people such as Newton, Leibniz or Voltaire, have

\section{Science's expansion has repercussions not only for society but also for science}

made way for an army of largely anonymous workers, a sign that science has levelled any status differences and become more democratic.

The other form of differentiation is through expansion into new fields. The more abstract and the more general the scientific methods and instruments, the more effectively they can be used to investigate new objects and phenomena. This growth-driven specialisation can be regarded as the motor of science's expansion into society as more fields succumb to its scrutiny. An illustrative example is the environmental sciences that originally expanded from ecology into a wide range of specialised fields now ranging from social risk assessment to environmental psychology. In fact, they are a paradigm
This expansion has led to a tighter coupling of science with various elements of society and has consequences for both. I will investigate in particular how the increasingly tight union between science, politics and the media is changing the face of science.

On March 28, 1979, Walter Cronkite began the CBS evening news by declaring that it was the 'most confused day in the history of news media' and went on to describe the contradicting information about the accident at the Three Mile Island nuclear reactor in Harrisburg, PA. Seven years later, a similar spectacle took place in Europe following the explosion in the Chernobyl nuclear power plant. Scientists and politicians contradicted each other in the media, exaggerating or downplaying the risks of the nuclear cloud that was moving towards Western Europe. It culminated in a politician publicly consuming salad on national television in a futile attempt to prove that the fallout from Chernobyl had left vegetables untouched.

Three Mile Island and Chernobyl became symbols not only of the dangers of nuclear energy, but also of the loss of public confidence in scientific authority (Weingart, 1979). The contradictory statements of scientific experts in public hearings showed that they had only been recruited to support specific positions and interests in politics and the economy. It destroyed the image of science as an institution that is free of interests other

\section{Three Mile Island and Chernobyl became symbols of the loss of public confidence in scientific authority}

for a new type of science, dubbed 'postnormal science', which is characterised by its close proximity to politics, its need for social legitimisation and its dependence on outside knowledge. than its own. Since then, the public has become aware of various other scientific/ technical dilemmas-the safety of genetic technologies, the ethical implications of reproduction techniques, the use of 


\section{viewpoint}

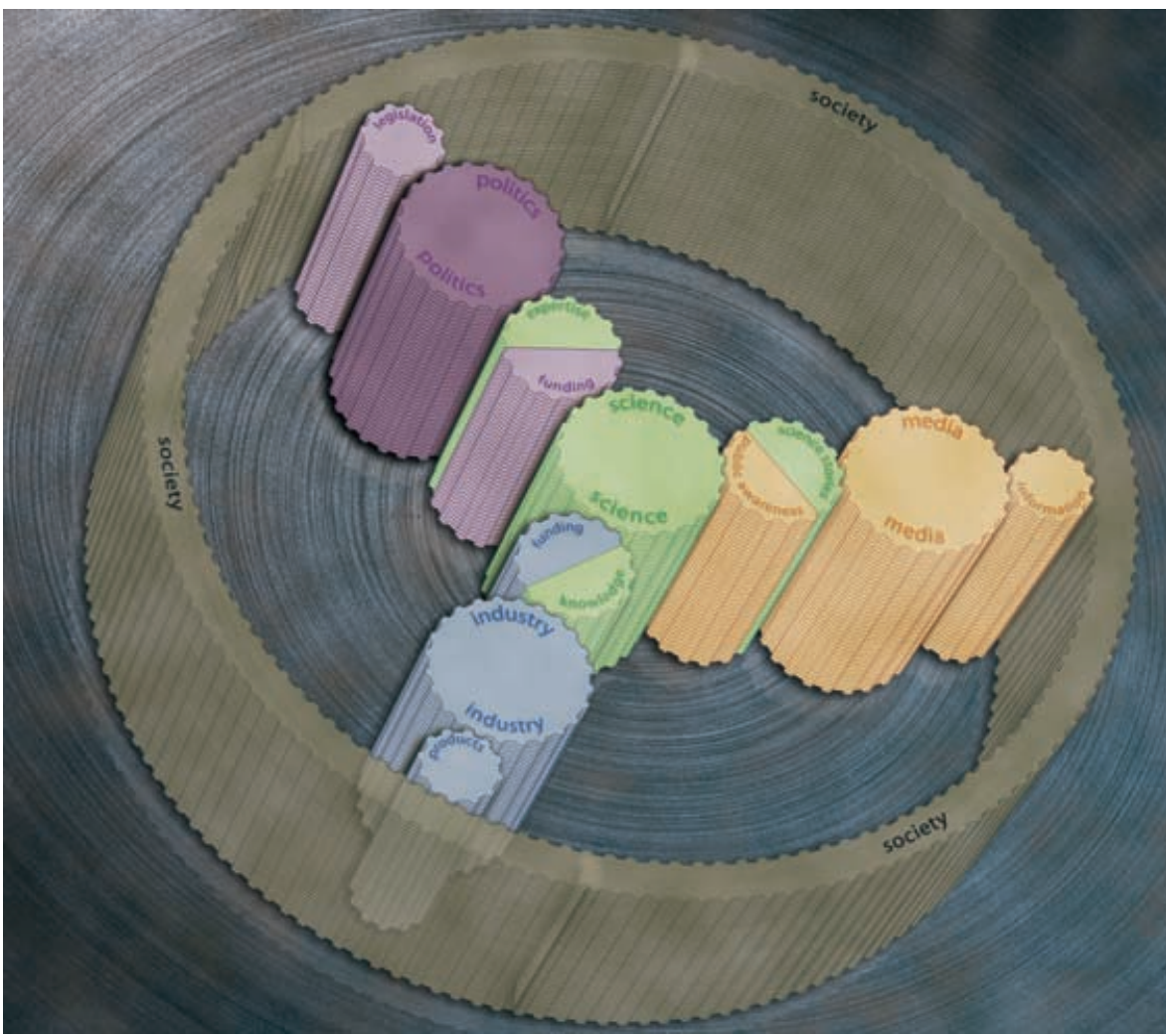

biotechnology in agriculture, the political, ethical and economic implications of the sequencing of the human genome, BSE, the potential dangers of electrosmog, to name but a few. It has become common practice for the parties involved in these controversies to engage scientific experts to present evidence that supports their cause.

At the time of the nuclear accidents, scientists were already frequent visitors to the corridors of power. In fact, the last 50 years have seen the establishment of a large scientific presence within governments, ministries and parliaments. Politics either requests special scientific expertise or creates its own in the form of research institutions controlled by ministries. Few remember that in the 1950 s the connection between science and politics was seen as more ambivalent-on the one hand as a guarantee that politics relied on rational and unbiased knowledge to make decisions in society's 'best interests', and on the other as a liaison dangereuse, where the political influence of nonelected scientific experts threatened the democratic system.

As scientific expertise became commonplace in politics, these initial fears gradually disappeared, mainly because expert knowledge became equally available to all groups in the political system.
This democratisation has led to an increasing competition for expertise. Surprisingly, however, this has not led to political decisions being more rational. In contrast, the controversies have become more intense and the lack of knowledge has become more apparent. But, despite the obvious absence of expert authority and rationality, the existing arrangement between science and politics continues nearly unchanged. And since there is no alternative to scientific expertise, the institutionalised coupling of science and politics is not likely to change in the future. What is changing are the borders between politics and science and how and where they are drawn.

The relationship between science and politics can be described as a recursive coupling of two interdependent developments - the scientification of politics and the politicisation of science (Weingart, 1983). One indicator of the former is that many political problems have been first recognised and described by scientistsenvironmental pollution, for instance, only made it on to the political agenda after scientists discovered DDT in the food chain. All debates about the risks of new technologies are, in fact, driven by research on the potential dangers and how to avoid them (Weingart, 1991, 1993). In other words, the more science becomes part of the governing process, the greater its role becomes in defining the problems that it is then asked to solve (Boehmer-Christiansen, 1995).

Vice versa, the coupling of knowledge with politics drives the politicisation of science. Knowledge, as it enters the public arena, is inevitably judged and valued by society. The expert's position in a controversy is thus seen as determined by politics and not by knowledge. 'Advisors are selected, not because members of parliament and officials from government need their advice, but because they obviously need their authoritative support for the policies they represent. By succumbing to these temptations, it is obvious that they fraudulently agree with the scientists, who exploit the prestige gained through objectivity and neutrality' (Shils, 1987). The assumption that science is always disinterested and transmits only objective knowledge is obviously a myth. Science has become one of the actors in the political arena, be it as an interested party or recruited by other actors to support their specific interests. The increasing demand for scientific expertise leads to an inflationary use of knowledge that fuels controversies. This oversupply of knowledge means that politics risks the loss of an important source of legitimisation, and science risks the loss of public confidence.

Science has also become closely interrelated with the media. In 1993, a Dutch researcher claimed to have found a vaccine against HIV. Pressed by his peers, he admitted that he had exaggerated his results because he felt it was the only way to gain public attention and support

Since there is no alternative to scientific expertise, the coupling of science and politics is not likely to change

(Hagendijk and Meeus, 1993). Such spectacular claims are a rather recent phenomenon in science and can be explained by the traditional model of popularising science. Historically, scientific knowledge has been regarded as superior and of higher value than popular knowledge or 'common sense'. Science 


\section{viewpoint}

produces 'true' knowledge, so specialised and esoteric that it needs to be translated and transmitted to the public by the media. The process is controlled by scientists-and from their point of view, popularised knowledge is simplification in the best case, contamination in the worst.

Another reaction of science is the increasing use of the media to mobilise public support. This is not due to unexplainable behavioural changes on the part of scientists but the increasing competition and the increasing social relevance of certain research fields. Scientists warn of

The assumption that science is always disinterested and transmits only objective knowledge is obviously a myth

This concept has two questionable implications. One is the belief that the public is a passive and non-specialised audience, excluded from the production and verification of knowledge and incapable of judging its value (Whitley, 1985). The other is that the role of the media is limited to translating knowledge. This notion still has too many supporters to be outdated. However, a new view has taken hold more recently that emphasises the independence of the media. There is a growing consensus that they 'create their own reality', using their own selection criteria depending on the use of information, their sources and their particular readership or viewership. (Dunwoody and Peters, 1993; Marcinkowsky, 1993; Luhmann, 1996). The most important criteria for journalists in selecting their stories are actuality, sensation, personalities and local implications-in short, they cover 'what is existent, what is happening and what is important' (Dunwoody and Peters, 1993). Clearly, these criteria are different from those that the scientific community uses to communicate information. The complaints about 'wrong' or 'distorted' media coverage and 'wrong' selection of news therefore do not reflect reality. There can be no 'adequate' presentation of science in the media in a way that satisfies scientists.

Science has begun to understand this notion and started to open its doors to the media. A striking example is the recently modernised 'public relations' (PR) departments of universities, research institutes, museums and other scientific organisations that use the same techniques as professional PR companies and produce the same glossy prospectuses. Universities, with varying degrees of success, give themselves a 'corporate design' similar to large companies. The effect on the public acceptance of science when it uses the tools of commercial advertisement remains to be seen.

global catastrophes, promise treatments for many ailments or solutions to solve mankind's problems in order to gain media attention that could increase the resources for their research. This strategy is particularly useful when the importance of the peer review system is diminished and politics influences the distribution of funds. Dorothy Nelkin showed that decisions concerning large research projects in particular are increasingly being made outside the traditional system of peer review, with the effect that external criteria gain importance (Nelkin, 1995). Consequently, funding decisions are dependent not only on potential social need but also on the potential media coverage, forcing scientists to resort to the strategy of 'selling their science to the public'.

A prime example is the field of climate research. The public debate about global warming was triggered in the USA by NASA scientist James Hansen and the prepublication of his research in the New York Times before the original article appeared in Science. The newspaper spoke of an 'unprecedented warming' of the atmosphere in the next century and warned of rising sea levels. Hansen quickly became the central figure in the global warming debate and the most important source for journalists. The topic reappeared on the political agenda in 1998 when Hansen explained to the US Congress that carbon dioxide and other

\section{Science, as society's early warning system, becomes neutralised and ignored as just one voice among many others}

artificially produced gases would increase the temperature of the atmosphere. This time it was a politician, Senator Timothy E. Wirth, who organised the media coverage. The result was additional funds from Congress for climate research.

Similarly, in Germany in 1986, the German Physical Society warned of a climate catastrophe and called for immediate action to regulate carbon dioxide production. The unusual dramatic tone of this warning created the intended media response-the German magazine Der Spiegel printed a picture of Cologne cathedral sinking in the sea, which became an icon for global warming. A commission created in 1987 to investigate the threat recommended a reduction in carbon dioxide release of $25-30 \%$ by 2005, and the German parliament followed this with a commitment to a $25 \%$ decrease. The success for the scientists was the institutionalisation and continued funding of climate research.

This pattern has been repeated regularly in the establishment of new research fields. In the beginning are dire warnings in the media about a looming danger, if not catastrophe. The scientists promise to find solutions, which results in funds for research. Once established, the new research field starts its life cycle; the knowledge increases, becomes more differentiated, specialised, abstract and increasingly irrelevant to the solution of the original problem.

This 'risk of communication' is similar to the Cassandra legend in Greek mythology. Justified warnings may be overlooked because there is no way to verify their truth. Science, as society's early warning system, becomes neutralised and ignored as just one voice among many others. 'The public image of politics is nearly exclusively determined by the media. [...] Trapped in a faster and faster spinning hamster wheel, politicians run behind their own agenda and do not realise how little of their work remains visible. The more that is proposed, criticised, questioned, rejected and resurrected, the less is left in the public view. [...] Politics cannot flourish in such a climate of extreme nervousness, vain talkativeness and uncritical closeness.

Disorder and loss of distance contribute to the ruin of politics; the trust in the actors is lost' (Kornelius, 1996). Stefan Kornelius described the consequences for politics, but his analysis may as well hold true for science. The strategy of using the media to generate public support for research is surely doomed to fail. Instead, 


\section{viewpoint}

it strengthens the suspicion that scientists have their own agenda and further endangers their public credibility.

It is a paradox-the more independent science and the media are, the tighter their coupling. And as the media gain importance, science is losing the monopoly of judging scientific knowledge. The abstract criterion of truth is no longer sufficient in the public debate because the media add the criterion of public acceptance. This does not mean that scientific verification is being replaced, but it is being supplemented by other measures.

The term 'information society' was originally coined in Japan at the beginning of the 1960s but has since found its way into European and US political rhetoric. But it is a rather misleading term-it is not information that will characterise future societies but the context-related production, appropriation and use of information in order to create knowledge. Consequently, the term information society is being gradually replaced by the term 'knowledge society'.

Irrespective of the description, the main problem is how science can produce and communicate reliable knowledge if the traditional means are outdated, if the distance between science and society and the resulting trust are replaced by tight coupling. As already discussed, three important tendencies in science show that this will be a major problem. First, science is increasingly influenced by politics. The use of scientific expertise by politicians and other groups in society involves science in making political decisions and installs scientists within political groups. Secondly, science is increasingly commercialised. Scientific knowledge is becoming a commodity that can be traded like any other product. Thirdly, science and the media are increasingly coupled as scientists use the media in order to raise public support for their research. All these trends point to a loss of distance between science and society, which has been the most important basis for the production of reliable knowledge.

One could conclude from these developments that science is losing its importance. But this is not quite correct. Science as an institution that produces knowledge remains irreplaceable. It rather means that the principles of science-the production and revision of knowledge-are being extended to other parts of society. Therefore, science is losing its position as the only institution that produces reliable knowledge. The point here is the valida-

\section{Science is losing its position as the only institution that produces reliable knowledge}

tion of truths. If science fails to do so, society will, the media will demand it and politics will create the necessary trust through legal frameworks.

This loss of distance will not lead to the end of the communication of truths. Trust and confidence remain both constitutive and rare values in communication, and the more society depends on reliable knowledge the more these are required. The main characterisation of today's society is the competition for trust. Once achieved, this is invaluable and science should be keen to preserve it. Therefore, it is only the efforts needed to produce trust and confidence that have become greater.

\section{References}

Bell, D. (1973) The Coming of Post-Industrial Society: A Venture in Social Forecasting. Basic Books, New York, NY.

Boehmer-Christiansen, S. (1995) Reflections on scientific advice and EC transboundary pollution policy. Science and Public Policy, 22, 195-203.

Dunwoody, S. and Peters, H.P. (1993) Massenmedien und Risikowahrnehmung. In Risiko ist ein Konstrukt. Bayrische Rück, Munich, Germany, pp. 317-341.

Hagendijk, R. and Meeus, J. (1993) Blind faith: fact, fiction and fraud in public controversies over science. Public Understanding of Science, 2, 391-415.

Kornelius, S. (1996) Ein irres System von hoher Geschwätzigkeit. Süddeutsche Zeitung, May 18.

Luhmann, N. (1996) Die Realität der Massenmedien. Westdeutscher Verlag, Opladen, Germany.

Marcinkowsky, F. (1993) Publizistik als autopoietisches System: Politik und Massenmedien-eine systemtheoretische Analyse. Westdeutscher Verlag, Opladen, Germany.

Nelkin, D. (1995) Science controversies. In Jasanoff et al. (ed.), Handbook of Science and Technology Studies. Thousand Oaks, London, UK, pp. 444-456.

Price, D.J. (1971) Little Science, Big Science. Columbia University Press, New York, NY.

Shils, E. (1987) Science and scientists in the public arena. The American Scholar, 65, 185-202.
Stichweh, R. (1984) Zur Entstehung des modernen Systems wissenschaftlicher Disziplinen. Physik in Deutschland. Suhrkamp, Frankfurt am Main, Germany.

von Helmholtz, H. (1896) Über das Verhältnis der Naturwissenschaften zur Gesamtheit der Wissenschaften. In von Helmholtz, H. (ed.), Vorträge und Reden. Vieweg und Sohn, Braunschweig, Germany.

Weingart, P. (1979) Das 'Harrisburg Syndrom' oder die De-Professionalisierung der Experten. In Nowotny, H. (ed.), Kernenergie: Gefahr oder Notwendigkeit. Suhrkamp, Frankfurt am Main, Germany, pp. 9-17.

Weingart, P. (1983) Verwissenschaftlichung der Gesellschaft-Politisierung der Wissenschaft. Zeitschrift für Soziologie, 12, 225-241.

Weingart, P. (1991) Large technical systems, reallife experiments, and the legitimisation trap of technology assessment: the contribution of science and technology to constituting risk perception. In LaPorte, T.R. (ed.), Social Responses to Large Technical System, Control or Anticipation. Kluwer, Dordrecht, The Netherlands, pp. 5-17.

Weingart, P. (1993) Welche Forschung ist gut? Bild der Wissenschaft, 5.

Whitley, R. (1984) The Intellectual and Social Organization of the Sciences. Clarendon Press, Oxford, UK.

Whitley, R. (1985) Knowledge producers and knowledge acquirers: popularisation as a relation between scientific fields and their publics. In Shinn T. and Whitley, R. (eds), Expository Science: Forms and Functions of Popularization. Yearbook Sociology of the Sciences IX, Reidel, Dordrecht, The Netherlands.

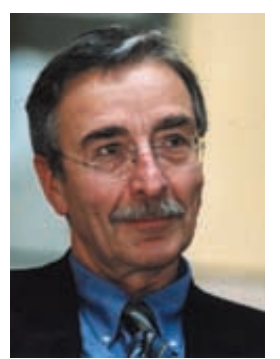

This article is an edited excerpt from Peter Weingart's book Die Stunde der Wahrheit? Zum Verhältnis der Wissenschaft zu Politik, Wirtschaft und Medien in der Wissensgesellschaft, published in 2001 by Velbrück Wissenschaften, Weilerswist, Germany. Translated and published with permission from Velbrück Wissenschaften.

Peter Weingart is Professor of Sociology at the Institute for Research on Science and Technology at the University of Bielefeld in Germany.

E-mail: pweingart@mail.uni-bielefeld.de

DOI: $10.1093 /$ embo-reports/kvf165 